\title{
Accumulation in Antarctica and Greenland derived from passive-microwave data: a comparison with contoured compilations
}

\author{
H. JAY ZWALLY \\ Oceans and Ice Branch, Code 971, Goddard Space Flight Center, Greenbelt, MD 20771, U.S.A. \\ Mario B. Giovinetto \\ Earth Sciences 356, University of Calgary, Calgary, Alberta T2N 1N4, Canada
}

\begin{abstract}
The annual rate of net mass accumulation at the surface in the Antarctic and Greenland ice sheets is determined from firn emissivity based on Nimbus-5 ESMR and Nimbus-7 THIR data. In this study the determinations are limited to the areas of dry-snow facies and are based on a hyperbolic function of emissivity. Two coefficients of the function are selected for particular regions of each ice sheet after a comparison with field data selected for their reliability 82 stations in East Antarctica, 69 stations in West Antarctica and 89 stations in Greenland). Derived accumulation values are produced for grid-point locations $100 \mathrm{~km}$ apart which cover $56-94 \%$ of the dry-snow areas and $32-58 \%$ of the accumulation areas of each ice sheet. These values are compared with interpolated values obtained from the latest contoured compilations of field data. The means of derived values for East and West Antarctica are $12 \%$ and $39 \%$ larger, respectively, than the mean obtained from interpolated values, suggesting that the isopleth patterns as drawn in the compilation of field data lead to underestimates. The mean of derived values for Greenland is $5 \%$ smaller than the mean obtained from interpolated values, suggesting that the compilation of field data may lead to small overestimates that are within the error of determination and the variability of accumulation. Improving facies zonation and the determination of coefficients for the areas of upper percolation facies should improve these preliminary assessments.
\end{abstract}

\section{INTRODUCTION}

The rate of net mass accumulation $\left(A\right.$, in $\left.\mathrm{kg} \mathrm{m}^{-2} \mathrm{a}^{-1}\right)$ at the surface (or surface balance) for particular locations in the Antarctic and Greenland ice sheets is derived from firn emissivity (Zwally, 1977). The derivations are based on a hyperbolic function of emissivity and are applicable to areas of dry-snow and upper-percolation facies (for a definition of terms refer to Benson (1962)). We limit the discussion to areas of dry-snow facies (Figs 1-3). The ice sheets are represented by circles centered at grid-point locations that correspond to the intersection of lines $100 \mathrm{~km}$ apart; the origin lines are set at longitudes of $0^{\circ}$ $180^{\circ}$ and $90^{\circ} \mathrm{W}-90^{\circ} \mathrm{E}$ for Antarctica, and $45^{\circ} \mathrm{W}$ and $135^{\circ} \mathrm{W}-45^{\circ} \mathrm{E}$ for Greenland (horizontal lines have " $y$ " numbers, and vertical lines, referred to as columns, have " $x$ " numbers). Graham Land and eastern Palmer Land in Antarctica, and ice caps which are not attached by ice in Greenland, are excluded from this study. The distribution of the areas of dry-snow facies is adopted with minor modifications from Giovinetto (1964a) for Antarctica and from Benson (1962) for Greenland (Table 1).

We first compare the derived accumulation obtained at stations $\left(A_{\mathrm{ds}}\right)$ for which there are reliable field measurements of accumulation $\left(A_{\mathrm{fs}}\right)$ to determine sets of coefficients of the function for each ice sheet. We then derive accumulation values for grid points $100 \mathrm{~km}$ apart $\left(A_{\mathrm{dg}}\right)$ and compare them with interpolated grid-point values obtained from the latest contoured compilations of field data $\left(A_{\mathrm{fg}}\right)$. The comparisons are an indirect assessment of the compilations. The $A_{\mathrm{dg}}$ values are produced by repeatable application of the emissivity method on the basis of evenly distributed remotely sensed data collected in 1973-79 and are means representative of periods of the order of 10 years ending in 1976 (Table 2). The $A_{\mathrm{fg}}$ values are obtained from isopleth patterns drawn following subjective interpolation and extrapolation criteria of unevenly distributed field data representative of periods ranging between orders of 1 and 100 years, although the bulk of the data is characterized by overlapping 10 year means distributed over about 45 years (roughly 1940-85).

\section{EMISSIVITY METHOD}

Our method for deriving the accumulation rate from satellite measurements of brightness temperature $T_{\mathrm{B}}$, in 

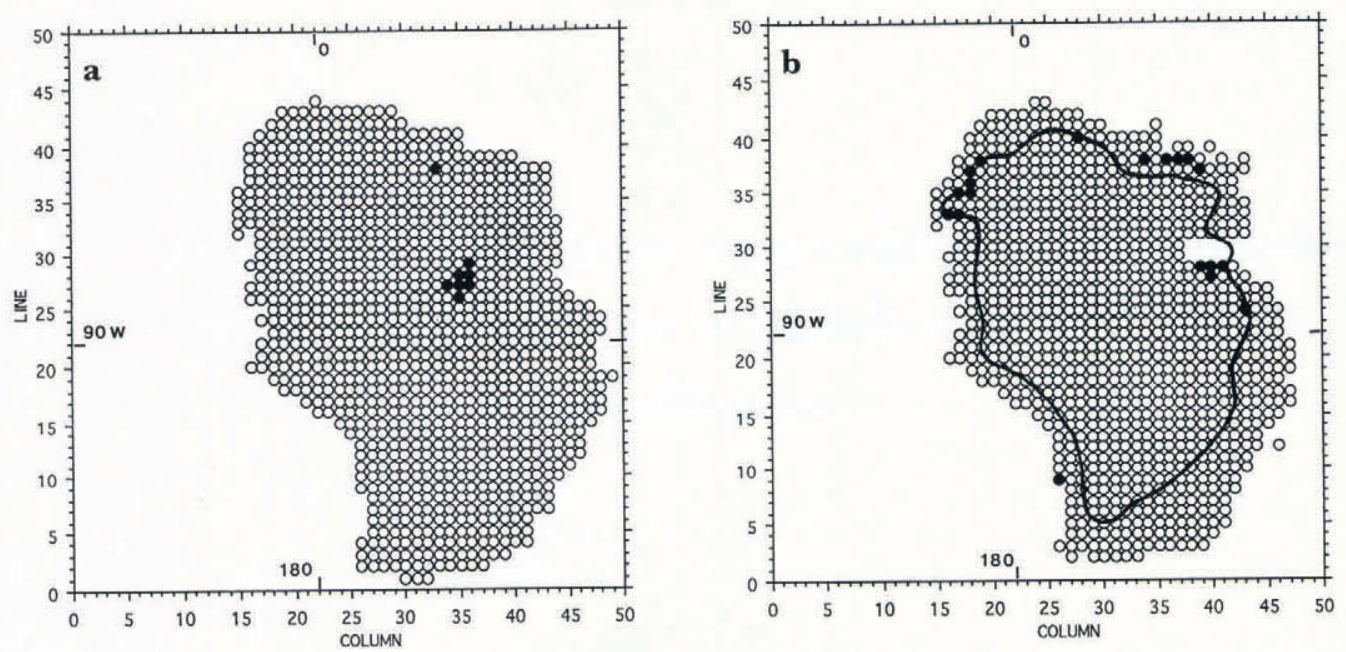

Fig. 1. East Antarctica. Circles are centered on grid points $100 \mathrm{~km}$ apart. a. Conterminous ice sheet; full circles show locations where net ablation at the surface has been indicated in some compilations. $b$. Area delimited by the dry-snow line; full circles indicate the location of points excluded from the sampled area.
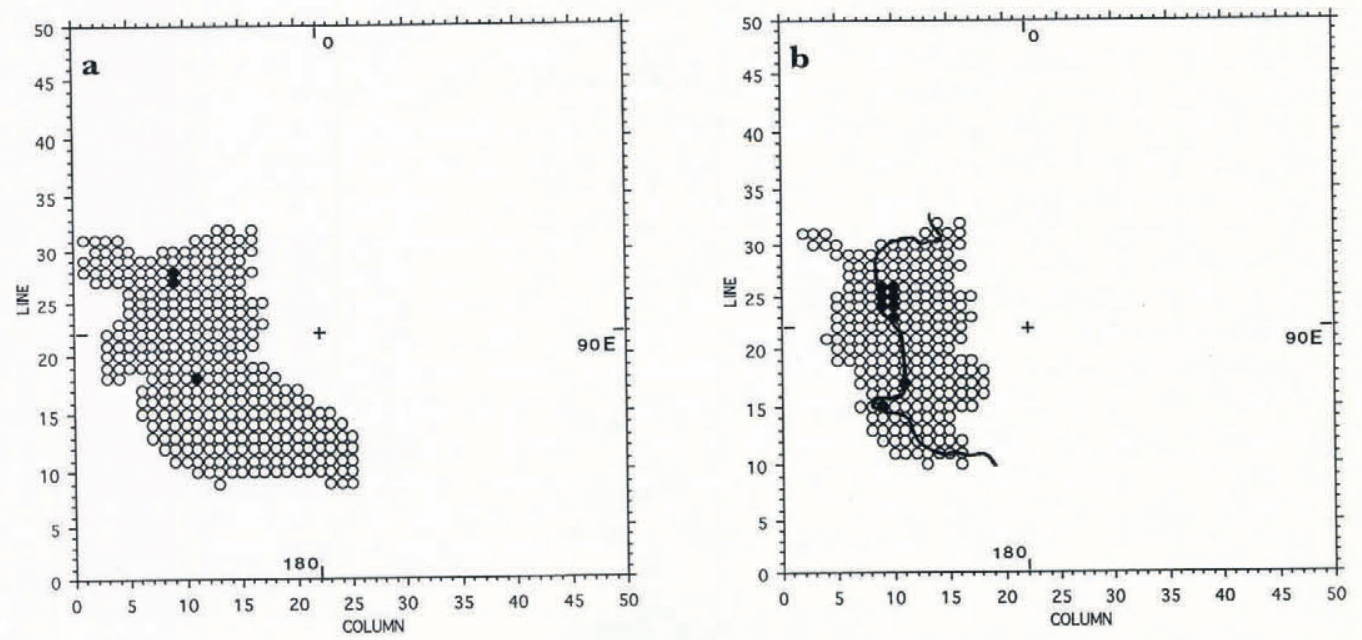

Fig. 2. West Antarctica. Circles are centered on grid points $100 \mathrm{~km}$ apart. a. Conterminous ice sheet. b. Area delimited by the dry-snow line; full circles indicate the location of points excluded from the sampled area.
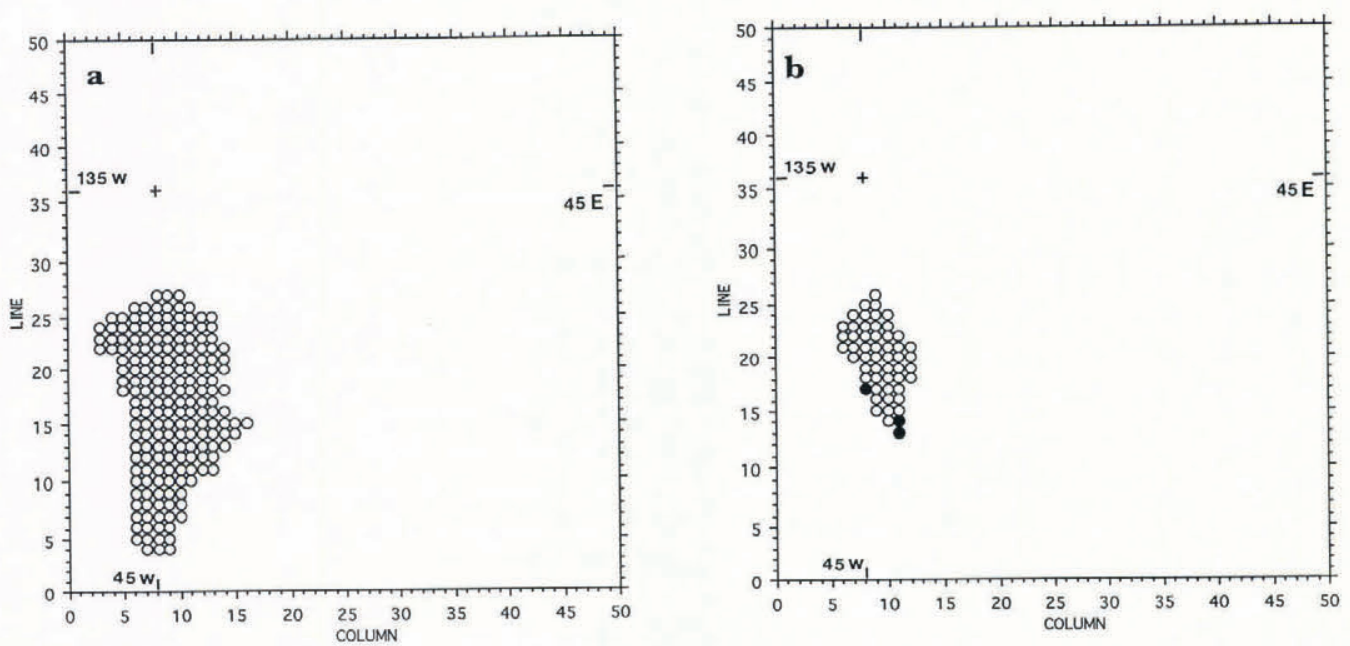

Fig. 3. Greenland. Circles are centered on grid points $100 \mathrm{~km}$ apart. a. Conterminous ice sheet. b. Area delimited by the drysnow line; full circles indicate the location of points excluded from the sampled area. 
Table 1. Areas of dry-snow facies. $\mathcal{N}$, number of grid points, each centered on a nominal area of $10^{4} \mathrm{~km}^{2} . E A$, East Antarctica; WA, West Antarctica; G, Greenland

\begin{tabular}{|c|c|c|c|c|c|}
\hline \multicolumn{2}{|c|}{ Ice sheet } & \multicolumn{4}{|c|}{ Area delimited by dry-snow line } \\
\hline Initials & $\begin{array}{c}\text { Area } \\
\mathcal{N}\end{array}$ & $\begin{array}{c}\text { Total } \\
\mathcal{N}\end{array}$ & $\begin{array}{c}\text { Sampled } \\
\mathcal{N}\end{array}$ & $\begin{array}{c}\text { Excluded } \\
\mathcal{N}\end{array}$ & $\begin{array}{c}\text { Assessment } \\
\mathcal{N}\end{array}$ \\
\hline EA & 1020 & 924 & 613 & 26 & 587 \\
\hline WA & 331 & 228 & 136 & 9 & 127 \\
\hline G & 187 & 54 & 54 & 3 & 51 \\
\hline
\end{tabular}

$\mathrm{K}$ ) and mean annual surface temperature $\left(T_{\mathrm{M}}\right.$, in $\left.\mathrm{K}\right)$ at particular locations is based on equations given by Zwally (1977). The $T_{\mathrm{B}}$ and $T_{\mathrm{M}}$ values are obtained by bilinear interpolation from $30 \mathrm{~km} \times 30 \mathrm{~km}$ grid-square Nimbus- 5 ESMR data $\left(T_{\mathrm{B}} 4\right.$ year mean, 1973-76 (Zwally and others, 1983; Parkinson and others, 1987)) and Nimbus-7 THIR data $\left(T_{\mathrm{B}}\right.$ for 1979 (Comiso, 1994)).

The connection between derived values and microwave emissivity $(E)$ is made by combining a solution of the radiative transfer equation with the grain-growth function given by Gow (1969). The parameter in both equations is the inverse gradient, $1 /\left(\mathrm{d} R^{3} / \mathrm{d} z\right)$, of the grain-size $(R)$ with depth $(z)$. Zwally (1977) gives $E$ as a function of $s=\mathrm{d} R^{3} / \mathrm{d} z$ from a simplified analytic solution of the radiative transfer equation (cf. Comiso and others, 1982; Van der Veen and Jezek, 1993). Replotting of the values in figure 1 of Zwally (1977) shows that $1 /\left(\mathrm{d} R^{3} / \mathrm{d} z\right)$ is approximately a hyperbolic function of $E$,

$$
1 /\left(\mathrm{d} R^{3} / \mathrm{d} z\right)=a_{0}+a_{1} /(0.95-E) .
$$

Equation (34) of Zwally (1977), which is derived from the grain-growth function given by Gow (1969), is

$$
R^{3} \approx R_{0}^{3}+\left[k p_{0} /\{A \exp (e / R T)\}\right] z
$$

where $k$ is a constant, $p_{0}$ is the average firn density in the top $10 \mathrm{~m}, e$ is the activation energy of the growth process, $R$ is the gas constant, and $T$ is the physical temperature. A value of $e / R$ equal to 5250 with $k p_{0}=10^{10}$ is obtained from fitting Equation (2) to the data of Gow (1969) on $R(z)$ using $T=T_{\mathrm{M}}$. Therefore, from Equation (2),

$$
1 /\left(\mathrm{d} R^{3} / \mathrm{d} z\right)=A \exp \left(5250 / T_{\mathrm{M}}\right)\left(10^{-10}\right)
$$

and

$$
A=\left[a_{0}+a_{1} /(0.95-E)\right] \exp \left(-5250 / T_{\mathrm{M}}\right)\left(10^{10}\right)
$$

which is the desired equation, using $E=T_{\mathrm{B}} / T_{\mathrm{M}}$ according to equation (46) of Zwally (1977).

The emissivity method requires accurate determination of $T_{\mathrm{B}}$ and $T_{\mathrm{M}}$. A change of $1 \mathrm{~K}$ in either $T_{\mathrm{B}}$ or $T_{\mathrm{M}}$ would result, on average, in a difference of $5 \%$ in the derived accumulation rate. Thus, the reliability of any comparison between derived and field accumulation is enhanced if $T_{\mathrm{M}}$ is determined from the same $30 \mathrm{~km} \times 30 \mathrm{~km}$ grid-square THIR database format used to determine $T_{\mathrm{B}}$.

\section{AREAL AND TEMPORAL VARIABILITIES}

The only 12 consecutive monthly mean series of surface temperature processed from the THIR database is for 1979 (Comiso, 1994). Although this is a short period, whatever uncertainties are introduced by the areal and temporal variability of surface temperature particular to that year, the value of $T_{\mathrm{M}}$ determined for 1979 is more representative of actual firn temperature to use with 1973-76 $T_{\mathrm{B}}$ data than the use of $10 \mathrm{~m}$ firn temperatures measured at different times between 1949 and 1990 (Table 2).

Table 2. Approximate periods represented by bulk of each data set

\section{Data set East Antarctica West Antarctica Greenland}

$\begin{array}{cccc}A_{\mathrm{ds}}, A_{\mathrm{dg}}{ }^{*} & 1940-76, & 1950-76, & 1956-75, \\ & 1960-76 & 1970-76 & 1968-75 \\ A_{\mathrm{fs}}{ }^{\dagger} & 1955-79 & 1955-90 & 1940-73 \\ A_{\mathrm{fg}}{ }^{\dagger} & 1940-83 & 1945-84 & 1940-85\end{array}$

\footnotetext{
* Remotely sensed data collected in 1973-76 and 1979.

† Field data collected in 1949-90 (Antarctica) and 195285 (Greenland).

\# Interpolated from compilations of field data collected up to 1985 .
}

The areal and temporal variabilities of accumulation (e.g. Giovinetto, 1964b) contribute to uncertainty in the comparisons between $A_{\mathrm{ds}}$ and $A_{\mathrm{fs}}$, and between $A_{\mathrm{dg}}$ and $A_{\text {fg. }}$. The contribution to uncertainty by the areal variability cannot be avoided, i.e., $A_{\mathrm{ds}}, A_{\mathrm{dg}}$ are values derived for each point from bilinear interpolations of average values of $T_{\mathrm{B}}$ and $T_{\mathrm{M}}$ centered on sensor-grid areas of $900 \mathrm{~km}^{2}$, whereas $A_{\mathrm{fs}}$ values are determined from field measurements at a point, and $A_{\mathrm{fg}}$ values are interpolated for a point.

The contribution to uncertainty by the temporal variability is less critical than it may appear because the optical depth of firn thickness of top strata contributing approximately two-thirds of the total external emission) is approximately $5 \mathrm{~m}$ (Zwally, 1977). Using the firn-density summaries of Kojima (1964) and the accumulation map of Giovinetto and Bentley (1985), we estimate that in Antarctica the derived values are means representative of periods with an overall range between 1940 and 1976 (Table 2). In Greenland, from the density profiles shown by Benson (1962) and the accumulation map of Ohmura and Reeh (1991), we estimate that the derived values are means representative of periods with an overall range between 1956 and 1975. The overall range of the periods represented in the $A_{\mathrm{fs}}$ data is between 1940 and 1990, and in the $A_{\mathrm{fg}}$ data between 1940 and 1985. Thus, the time overlap between the derived and field data sets is $>1 / 2$ and $<3 / 4$. 


\section{COMPARISON WITH FIELD DATA}

Initial values of the coefficients $a_{0}$ and $a_{1}$ are chosen by curve fitting $\left(A \exp \left(5250 / T_{\mathrm{M}}\right)\right)$ to the hyperbolic function of $T_{\mathrm{B}} / T_{\mathrm{M}}$ in Equation (4), using $A_{\mathrm{ds}}$ and $A_{\mathrm{fs}}$ values. Preliminary studies of the emissivity method were made using field data from 357 stations in Antarctica and 89 stations in Greenland; the sources of $A_{\mathrm{fs}}$ data are listed elsewhere (paper in preparation by H.J. Zwally and others). The Antarctic $A_{\mathrm{fs}}$ data sets selected were those in which accumulation was obtained by the radioactive- or stable-isotope method, or by the stakenetwork method; if obtained by the stratigraphic method, only those sets for which the rate could be substantiated by one of the other methods were selected. The $A_{\mathrm{fs}}$ data sets for Greenland do include sets in which the stratigraphic method was the only one used to obtain the rate, i.e., all methods were considered equally reliable.

In the areas of dry-snow facies, values of $E$ range from 0.63 to 0.88 in the Antarctic data, and from 0.67 to 0.81 in the Greenland data. In the latter data set, the emissivity approaches its asymptotic value of 0.95 (Equation (4)) when included in the fit as the third adjustable coefficient. The value of 0.95 is also consistent with the asymptotic value in the solutions of the radiative transfer equations (Zwally, 1977; Comiso and others, $1982)$. Thus, the asymptotic value of $E$ is fixed at 0.95 , and the coefficients $a_{0}$ and $a_{1}$ are then adjusted to optimize the linear correlation between $A_{\mathrm{ds}}$ values as derived from Equation (4) and $A_{\mathrm{fs}}$ values to give a linear slope of unity and intercept of zero.

The preliminary values for the coefficients were $a_{0}=-5$ and $a_{1}=6.5$ for Antarctica, and $a_{0}=-32$ and $a_{1}=15.5$ for Greenland. The results are summarized in Table 3. The regression coefficient $(r)$ is 0.82 for Antarctica and 0.89 for Greenland. The root mean square (rms) of the residuals is relatively large for Antarctica $\left(90 \mathrm{~kg} \mathrm{~m}^{-2} \mathrm{a}^{-1}\right)$ and relatively small for Greenland $\left(36 \mathrm{~kg} \mathrm{~m}^{-2} \mathrm{a}^{-1}\right)$.

The scatter pattern in the Antarctic data indicated that at least two sets of coefficients $a_{0}$ and $a_{1}$ for Equation (4) are required for Antarctica: one set where the rate of accumulation is low and firn is exposed to large temperature gradients near the surface for several years (e.g. the plateau area in East Antarctica where $A_{\mathrm{fg}}<$ $100 \mathrm{~kg} \mathrm{~m}^{-2} \mathrm{a}^{-1}$ or approximately $50 \%$ of the area of the ice sheet); another where snow grains drift at relatively high speed and for relatively long distance before final deposition (e.g. the interior of West Antarctica and the southern area of major ice shelves where $A_{\text {fg }}<200 \mathrm{~kg}$ $\left.\mathrm{m}^{-2} \mathrm{a}^{-1}\right)$. The 100 and $200 \mathrm{~kg} \mathrm{~m}^{-2} \mathrm{a}^{-1}$ isopleths enclose nearly $50 \%$ and $80 \%$, respectively, of the area of the ice sheet (Giovinetto and Bull, 1987).

The data also showed widespread scatter where $A_{\mathrm{dg}}, A_{\mathrm{fg}}>200 \mathrm{~kg} \mathrm{~m}^{-2} \mathrm{a}^{-1}$, i.e. in that area of Antarctica where most of the accumulation data were obtained by the stratigraphic method, and where sporadic melting (Zwally and Fiegles, 1994) may affect emissivity. Therefore, the field data for Antarctica selected to determine the coefficients were first reduced to include only accumulation data obtained by radioactive- or stable-isotope method, and split between East and West Antarctica (Figs 4a and 5a). The data consist of 82 stations in East Antarctica (Picciotto and others, 1971; Vinogradov and Lorius, 1972; Young and others, 1982) and 69 stations in West Antarctica including the areas of dry-snow facies in the Ross and Filchner-Ronne ice shelves (Clausen and others, 1979; Reinwarth and Graf, 1985; Whillans and Bindschadler, 1988; personal communication from I. M. Whillans, 1993).

The data sets listed above were used to determine the values for the coefficients; these are $a_{0}=-20$ and $a_{1}=14.75$ for East Antarctica, and $a_{0}=-40$ and $a_{1}=$ 14.5 for West Antarctica (Table 3).

The scatter pattern for Greenland is rather uniform across the whole range of accumulation (Fig. 5a), and the coefficients are adopted as determined in the preliminary analysis (Table 3 ) on the basis of field data for 89 stations (Koch and Wegener, 1930; Paterson, 1955; Hamilton, 1956; U.S. Army Transportation Board, 1960; Langway, 1961; Benson, 1962; Mock and Alford, 1964; Quervain, 1969; Clausen and others, 1988).

The regression coefficients for East and West Antarctica are 0.79 and 0.82 , respectively. In each case, the rms of the residuals is smaller than for the larger data set (N357): $16 \mathrm{~kg} \mathrm{~m}^{-2} \mathrm{a}^{-1}$ for East Antarctica and $37 \mathrm{~kg}$ $\mathrm{m}^{-2} \mathrm{a}^{-1}$ for West Antarctica. This is partly because there is a better correlation between $A_{\mathrm{ds}}$ and $A_{\mathrm{fs}}$ values, and partly because the $A_{\mathrm{fs}}$ data do not exceed values of $125 \mathrm{~kg} \mathrm{~m}^{-2} \mathrm{a}^{-1}$ in East Antarctica or $220 \mathrm{~kg} \mathrm{~m}^{-2} \mathrm{a}^{-1}$ in West Antarctica. Therefore, we will tentatively limit the comparison between $A_{\mathrm{dg}}$ and $A_{\mathrm{fg}}$ values to areas where $A_{\mathrm{fg}}<101 \mathrm{~kg} \mathrm{~m}^{-2} \mathrm{a}^{-1}$ in East Antarctica, and $A_{\mathrm{fg}}<201 \mathrm{~kg}$ $\mathrm{m}^{-2} \mathrm{a}^{-1}$ in West Antarctica.

Table 3. Summary statistics of station data $\left(A_{\mathrm{ds}}=f\left(A_{\mathrm{fs}}\right)\right) . A$, Antarctica; $G$, Greenland; EA, East Antarctica; WA, West Antarctica

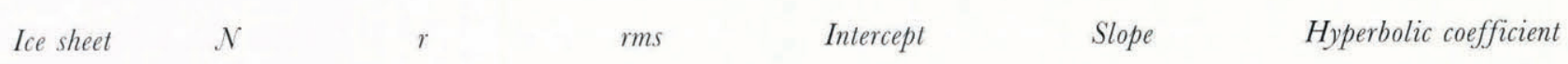

$a_{0}$

0.818

0.666

35.7

0.891

EA

0.793

WA
0.820

$\begin{array}{rr}90.1 & 0.818 \\ 35.7 & 0.666 \\ 15.5 & -0.657 \\ 37.4 & -1.234\end{array}$

\subsection{7}

1.018

0.984

1.137

$-5$

$-32$

$-20$

$-40$

$a_{1}$ 

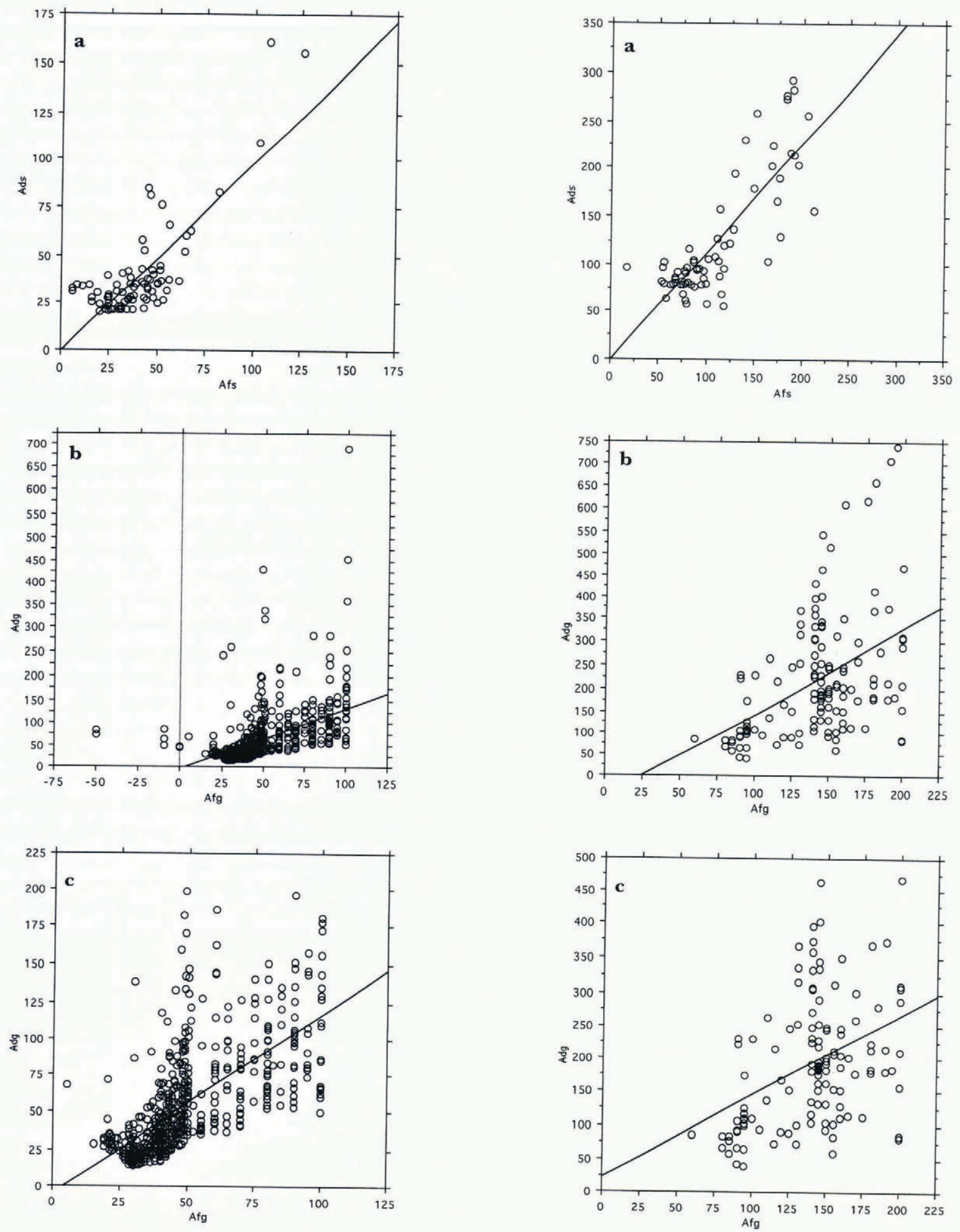

Fig. 4. East Antarctica. Scattergrams of accumulation values (in $\mathrm{kg} \mathrm{m}^{-2} \mathrm{a}^{-1}$ ) derived from emissivity $\left(A_{\mathrm{ds}}, A_{\mathrm{dg}}\right)$ and determined from field data $\left(A_{\mathrm{fs}}, A_{\mathrm{fg}}\right)$. a. Station data. b. Sampled grid-point data. c. Grid-point data after exclusions.

\section{COMPARISON OF GRID-POINT DATA}

In this section we compare $A_{\mathrm{dg}}$ and $A_{\mathrm{fg}}$ values for gridpoint locations in Antarctica and Greenland. In Antarctica, the areas of dry-snow facies are sampled by 1152 grid-point locations for which $A_{\mathrm{fg}}$ values are interpolated from the contoured compilation of field data by
Giovinetto and Bentley (1985). It should be noted, however, that seven locations for which $A_{\mathrm{fg}}$ values are negative (Fig. la, lines 26-29, columns 34-36) lie in the northern region of the Lambert Glacier basin, an area for which net ablation at the surface has been inferred from Landsat imagery (McIntyre, 1985). If the rate of accumulation in those locations is negative, most or all 
of the ablation in that region is due to snow deflation and sublimation and for the purposes of this study should be included in the dry-snow data set.

Derived values are obtained for 613 locations in East Antarctica where $A_{\text {fg }}<101 \mathrm{~kg} \mathrm{~m}^{-2} \mathrm{a}^{-1}$ (Fig. 4b; Table 4). The correlation is weak $(r=0.51$, rms $=51)$, and the mean of $A_{\mathrm{dg}}$ is $27 \%$ larger than that of $A_{\mathrm{fg}}$ values. There are 19 locations where $\left(A_{\mathrm{dg}}-A_{\mathrm{fg}}\right)>200 \mathrm{~kg} \mathrm{~m}^{-2} \mathrm{a}^{-1}$ (Fig. 1b). These are either in mountain areas or where Nimbus-5 ESMR data have occasionally shown differences of $30 \mathrm{~K}$ in $T_{\mathrm{B}}$ over the annual mean, which indicates melting (Zwally and Fiegles, 1994).

The $A_{\text {fg }}$ values for the seven locations in the northern region of the Lambert Glacier basin range between 0 and $75 \mathrm{~kg} \mathrm{~m}^{-2} \mathrm{a}^{-1}$. $A_{\mathrm{dg}}$ values for the same locations range between 43 and $232 \mathrm{~kg} \mathrm{~m}^{-2} \mathrm{a}^{-1}$, supporting an earlier estimate of positive accumulation in the region (Allison and others, 1985).

If we discount the 19 locations in mountain areas or where occasional melting affects emissivity, and the seven locations in the Lambert Glacier basin, the reduced data set $(N=587$; Fig. 4c; Table 4$)$ shows a moderate correlation $(r=0.67)$ and a much smaller scatter $(\mathrm{rms}=$ 27). This improvement in the statistics, and the difference between the means $\left(A_{\mathrm{dg}}=55 \mathrm{~kg} \mathrm{~m}^{-2} \mathrm{a}^{-1}, A_{\mathrm{fg}}=49 \mathrm{~kg}\right.$ $\mathrm{m}^{-2} \mathrm{a}^{-1}$ ), suggests that the compilation would lead to underestimates of accumulation of $12 \%$, rather than the $27 \%$ mentioned above.

Derived values are obtained for 136 locations in West Antarctica where $A_{\mathrm{fg}}<201 \mathrm{~kg} \mathrm{~m}^{-2} \mathrm{a}^{-1}$ (Fig. 5b; Table 4). The correlation is weak $(r=0.44, \mathrm{rms}=123)$, and the mean of $A_{\mathrm{dg}}$ is $55 \%$ larger than that of $A_{\mathrm{fg}}$ values. There are nine locations where $\left(A_{\mathrm{dg}}-A_{\mathrm{fg}}\right)>400 \mathrm{~kg} \mathrm{~m}^{-2} \mathrm{a}^{-1}$ (Fig. 2b). These are in mountain areas or near grounding lines, or where Nimbus-5 ESMR data indicate occasional melting (Zwally and Fiegles, 1994). There are three other locations in this group, one (Fig. 2a, line 18, column 11) lying approximately $200 \mathrm{~km}$ east-northeast of Byrd Station, and two (Fig. 2a, lines 27 and 28, both on column 9) lying on the Ronne Ice Shelf, approximately $120 \mathrm{~km}$ southeast of the Hauberg Mountains. Several locations in the Amundsen Sea sector and in the southwest of the Ronne Ice Shelf show $A_{\mathrm{dg}}$ values that are larger than $A_{\mathrm{fg}}$ values, suggesting that the drawing of isopleths on the basis of extrapolation of field data (as of 1985 there were only a few stratigraphic observations in those areas) leads to underestimates of accumulation in those regions. Other issues have been discussed elsewhere (Giovinetto and others, 1989).

If the nine locations mentioned above are discounted, the reduced data set $(N=127$; Fig. 5 c; Table 4$)$ shows an even weaker correlation $(r=0.41)$, but, of relevance to our discussion, a significantly smaller scatter $(\mathrm{rms}=88)$. Despite the weaker correlation (which, like all others mentioned in this paper, is significant at the 0.99 confidence level), the difference between the means $\left(A_{\mathrm{dg}}=195 \mathrm{~kg}\right.$ $\left.\mathrm{m}^{-2} \mathrm{a}^{-1}, A_{\mathrm{fg}}=140 \mathrm{~kg} \mathrm{~m}^{-2} \mathrm{a}^{-1}\right)$ suggests that the compilation would lead to underestimates of accumulation of $39 \%$, rather than the $55 \%$ mentioned above.

In Greenland, the area delimited by the dry-snow line is sampled by 54 grid-point locations, the $A_{\mathrm{fg}}$ values for which are interpolated from the contoured compilation of field data by Ohmura and Reeh (1991) (Fig. 3b). Derived values are obtained for these locations (Table 4; Fig. 6b). The correlation is robust $(r=0.89, \mathrm{rms}=43)$, and the mean of $A_{\mathrm{dg}}$ is $4 \%$ larger than that of $A_{\mathrm{fg}}$ values, a practically insignificant difference because it is within the error of determination of accumulation at particular sites.

There are three locations for which the contribution to the rms matrix is largest (Fig. 2b). All three lie close to the delineation of the dry-snow line. We are currently examining Nimbus-5 ESMR and Nimbus-7 SMMR

Table 4. Summary statistics of grid data

\begin{tabular}{|c|c|c|c|c|c|c|c|}
\hline \multirow[t]{2}{*}{ Data set } & \multirow[t]{2}{*}{$\mathcal{N}$} & \multirow[t]{2}{*}{ Mean } & \multirow[t]{2}{*}{ S.d. } & \multirow[t]{2}{*}{ Min. } & \multirow[t]{2}{*}{ Max. } & \multicolumn{2}{|c|}{$A_{\mathrm{dg}}=f\left(A_{\mathrm{fg}}\right)$} \\
\hline & & & & & & $r$ & $\mathrm{rms}$ \\
\hline $\mathrm{EA}, A_{\mathrm{dg}}$ & 613 & 62.6 & 58.8 & 14.4 & 691.7 & & \\
\hline$A_{\text {. }}$ & 612 & & & -500 & 1000 & 0.512 & 50.6 \\
\hline $\begin{array}{r}A_{\mathrm{fg}} \\
\mathrm{EA}, A_{\mathrm{dg}}\end{array}$ & $\begin{array}{l}613 \\
507\end{array}$ & 49.1 & $\begin{array}{l}22.0 \\
364\end{array}$ & $\begin{array}{r}-30.0 \\
14.4\end{array}$ & $\begin{array}{l}100.0 \\
198.8\end{array}$ & & \\
\hline & 501 & 55.1 & 30.4 & & & 0.670 & 27.1 \\
\hline$A_{\text {fg }}$ & 587 & 49.3 & 20.2 & 5.0 & 100.0 & & \\
\hline WA, $A_{\mathrm{dg}}$ & 136 & 220.6 & 136.8 & 41.2 & 739.3 & 0.442 & 123.2 \\
\hline$A_{\mathrm{fg}}$ & 136 & 142.2 & 32.2 & 60.0 & 200.0 & & \\
\hline WA, $A_{\mathrm{dg}}$ & 127 & 195.0 & 95.8 & 41.2 & 468.5 & 0.411 & 87.7 \\
\hline$A_{\mathrm{fg}}$ & 127 & 140.4 & 32.2 & 60.0 & 200.0 & & \\
\hline $\mathrm{G}, A_{\mathrm{dg}}$ & 54 & 200.2 & 92.4 & 101.4 & 419.5 & 0.888 & 42.9 \\
\hline$A_{\mathrm{fg}}$ & 54 & 207.9 & 83.8 & 90.0 & 450.0 & & \\
\hline $\mathrm{G}, A_{\mathrm{dg}}$ & 51 & 190.7 & 84.7 & 101.4 & 419.5 & 0.945 & 28.0 \\
\hline$A_{\text {fg }}$ & 51 & 200.0 & 77.1 & 90.0 & 400.0 & & \\
\hline
\end{tabular}



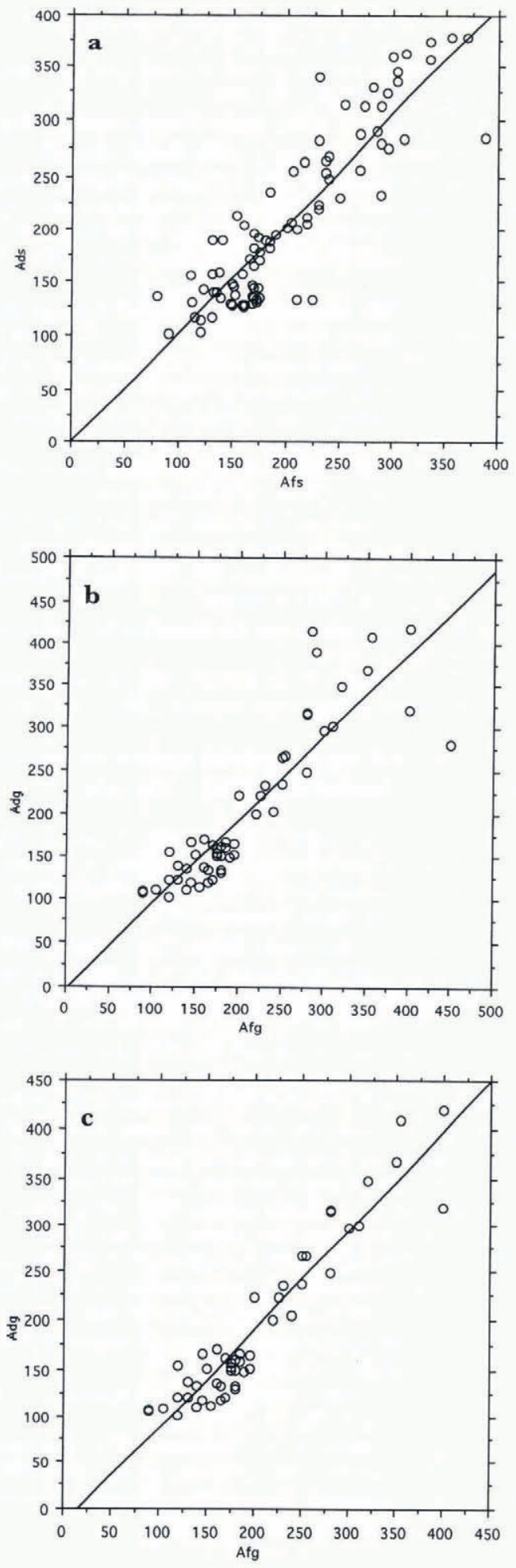

Fig. 6. Greenland. Scattergrams of accumulation values (in $\left.\mathrm{kg} \mathrm{m}^{-2} \mathrm{a}^{-1}\right)$ derived from emissivity $\left(A_{\mathrm{ds}}, A_{\mathrm{dg}}\right)$ and determined from field data $\left(A_{\mathrm{fs}}, A_{\mathrm{fg}}\right)$. a. Station data. $b$. Sampled grid-point data. c. Grid-point data after exclusions.

data for indications of melting. Assuming that the locations lie below the dry-snow line and are discounted, the improvement in the statistics for the reduced data set $(N=51$, Table 4 ; Fig. 6c) is quite remarkable $(r=0.95, \mathrm{rms}=28)$. The difference between the means of the smaller data sets $\left(A_{\mathrm{dg}}=190.7 \mathrm{~kg}\right.$ $\left.\mathrm{m}^{-2} \mathrm{a}^{-1}, A_{\text {fg }}=200.0 \mathrm{~kg} \mathrm{~m}^{-2} \mathrm{a}^{-1}\right)$ suggest that the compilation of field data would lead to an overestimate of $5 \%$ instead of the $4 \%$ mentioned above.

\section{DISCUSSION}

The compilation from which the $A_{\text {fg }}$ values were interpolated for Antarctica Giovinetto and Bentley, 1985) was based on $A_{\mathrm{fs}}$ data for the whole ice sheet (approximately 1500 stations and stake-network segments distributed along traverse routes) with the exception of the contours drawn in the northern Lambert Glacier basin (as described above). The fact that in both East and West Antarctica the mean of $A_{\mathrm{dg}}$ is larger than that of $A_{\mathrm{fg}}$ suggests that the subjective criteria used in the interpolation and extrapolation of isopleths results in an underestimate.

The $A_{\mathrm{fs}}$ data used to select the coefficients are heavily weighted by the data of Picciotto and others (1971) for western Dronning Maud Land in East Antarctica, and of Whillans and Bindschadler (1988) and I. M. Whillans (personal communication, 1993) for western Marie Byrd Land. It will be of interest to compare how the coefficients determined for East and West Antarctica would change when the results of field data being collected on, or analyzed for, the northern Amery Ice Shelf drainage system (including the northern area of the Lambert Glacier basin) and the southwestern Ronne Ice Shelf drainage system, are released. Preliminary maps of residuals $\left(A_{\mathrm{dg}}-A_{\mathrm{fg}}\right)$ show distinct nucleation of positive anomalies in those areas.

The compilation from which the $A_{\mathrm{fg}}$ values were interpolated for Greenland Ohmura and Reeh, 1991) was based on data for 251 stations distributed along traverse routes in the accumulation zone and precipitation data for 35 meteorological stations, mostly located along the coast, which provided ancillary information for the interpolation and extrapolation criteria used to draw the isopleths. The $A_{\mathrm{fs}}$ data used to determine the coefficients do not show any particular bias. Preliminary maps of residuals $\left(A_{\mathrm{dg}}-A_{\mathrm{fg}}\right)$ show near-zero anomalies in both the north and south of the area of dry-snow facies; they also show generally slightly negative anomalies to the west and slightly positive anomalies to the east of the central ridge.

\section{CONGLUSION}

The method of determining accumulation using a hyperbolic function of firn emissivity appears to be reliable for the areas of dry-snow facies, provided that there are adequate and reliable field data to determine the coefficients in the function. The derived accumulation for Antarctica suggests that estimates based on the contoured compilation of Giovinetto and Bentley (1985) would lead to underestimates, particularly in West Antarctica. The determinations of the sets of coefficients for East and West Antarctica need refinement because the distribution of reliable field data available at present for either ice sheet shows regional bias. The derived accumulation for Greenland suggests that the compilation of Ohmura and Reeh (1991) may lead to over-estimates by a small margin that presently is within the error of determination of accumulation at particular locations.

A more accurate facies zonation (e.g. Fahnestock and others, 1993; Zwally and Fiegles, 1994) is needed in both Antarctica and Greenland. The change in the areal 
distribution of the accumulation rate suggested by the derived values indicates that the full area coverage of brightness temperature and surface temperature data available from passive-microwave satellite observations would help remove inaccuracies inherent in the interpolation and extrapolation over long distances of field data. The full use of passive-microwave databases $(25 \mathrm{~km} \times 25 \mathrm{~km}$ and $30 \mathrm{~km} \times 30 \mathrm{~km}$ grid-squares $)$ rather than the $100 \mathrm{~km}$ grid approach used in this paper should allow the refinement of estimates of the accumulation rate for large parts of the ice sheets as well as of particular drainage systems.

\section{ACKNOWLEDGEMENTS}

The authors wish to thank C.R. Bentley for commentaries and discussion of early versions of this paper, as well as an anonymous reviewer for suggestions.

\section{REFERENGES}

Allison, I., N. W. Young and T. Medhurst. 1985. Correspondence: On re-assessment of the mass balance of the Lambert Glacier drainage basin, Antarctica. 7. Glaciol., 31(109), 378-381.

Benson, C.S. 1962. Stratigraphic studies in the snow and firn of the Greenland ice sheet. SIPRE Res. Rep. 70.

Clausen, H. B., W. Dansgaard, J. O. Nielsen and J. W. Clough. 1979 Surface accumulation on Ross Ice Shelf. Antarct. J. U.S., 14 (5), 68-72.

Clausen, H. B., N.S. Gundestrup, S.J. Johnsen, R. Bindschadler and J. Zwally. 1988. Glaciological investigations in the Crête area, central Greenland: a search for a new deep-drilling site. Ann. Glaciol., 10, 10-15.

Comiso, J.C. 1994. Surface temperatures in the polar regions from Nimbus 7 temperature humidity infrared radiometer. 7. Geophys. Res., 99 (C3), 5181-5200.

Comiso, J. C., H.J. Zwally and J. L. Saba. 1982. Radiative transfer modeling of microwave emission and dependence on firn properties. Ann. Glaciol., 3, $54-58$.

Fahnestock, M., R. Bindschadler, R. Kwok and K. Jezek. 1993. Greenland ice sheet surface properties and ice dynamics from ERS-1 SAR imagery. Science, 262 (5139), 1530-1534.

Giovinetto, M.B. 1964a. Distribution of diagenetic snow facies in Antarctica and in Greenland. Arctic, 17 (1), 32 40.

Giovinetto, M.B. 1964b. The drainage systems of Antarctica: accumulation. Antarct. Res. Ser., 2, 127-155.

Giovinetto, M.B. and C.R. Bentley. 1985. Surface balance in ice drainage sytems of Antarctica. Antarct. J. U.S., 20(4), 6-13.

Giovinetto, M. B. and C. Bull. 1987. Summary and analysis of surface mass balance compilations for Antarctica, 1960-1985. Byrd Polar Research Center. Report 1.

Giovinetto, M.B., C. R. Bentley and C.B.B. Bull. 1989. Choosing between some incompatible regional surface-mass-balance data sets in Antarctica. Antarcl. 7. U.S., 24(1), 7-13.

Gow, A.J. 1969. On the rates of growth of grains and crystals in South Polar firn. 7. Glaciol., 8(53), 241-252.

Hamilton, R. A. and 6 others. 1956. British North Greenland Expedition 1952 4: scientific results. Geogr. 7., 122, Part 2, 203-240.

Koch, J.P. and A. Wegener. 1930. Wissenschaftliche Ergebnisse der dänischen Expedition nach Dronning Louise-Land und quer über das Inlandeis von Nordgrönland 1912-13. Medd. Gronl., 75.

Kojima, K. 1964. Densification of snow in Antarctica. Antarct. Res. Ser., 2, $157-218$.

Langway, C. C., Jr. 1961. Accumulation and temperature on the inland ice of North Greenland, 1959. J. Glaciol., 3(30), 1017-1044.

McIntyre, N. F. 1985. A re-assessment of the mass balance of the Lambert Glacier drainage basin, Antarctica. f. Glaciol., 31(107), 34-38.

Mock, S.J. and D. L. Alford. 1964. Installation of ice movement poles in Greenland. CRREL Spec. Rep. 67.

Ohmura, A. and N. Reeh. 1991. New precipitation and accumulation maps for Greenland. f. Glaciol., 37(125), 140-148.

Parkinson, C. L., J. C. Comiso, H. J. Zwally, D. J. Cavalieri, P. Gloersen and W.J. Campbell. 1987. Arctic sea ice, 1973-1976: satellite passivemicrowave observations. Washington, DC, National Aeronautics and Space Administration. (NASA SP-489.)

Paterson, W. S. B. 1955. Altitudes on the inland ice in North Greenland. Medd. Gronl., $137(1), 1-12$.

Picciotto, E., G. Crozaz and W. de Breuck. 1971. Accumulation on the South Pole-Queen Maud Land traverse, 1964 1968. Antart. Res. Ser., 16, 257-315.

Quervain, M. de. 1969. Schneekundliche Arbeiten der Internationalen Glaziologischen Grönlandexpedition (Nivologie). Medd. Gronl., $177(4)$.

Reinwarth, O. and W. Graf. 1985. Neuere Untersuchungen zur Akkumulation auf dem Filchner/Ronne-Shelfeis. In Kohnen, H., ed. Filchner-Ronne-Ice-Shelf-Programme Report No. 2. Bremerhaven, Alfred Wegener Institute for Polar Research, 7-17.

United States Army Transportation Board. 1960. Report of environmental operation Lead Dog, 1960. Fort Eustis, VA, U.S. Army Transportation Board. (Project Lead Dog. Final Report TCB-60-023-EO.)

Van der Veen, C.J. and K. C. Jezek. 1993. Seasonal variations in brightness temperature for Central America. Ann. Glaciol., 17, 303306.

Vinogradov, O. N. and C. Lorius. 1972. Evaluation of the results of snow accumulation measurements along the Mirny observatory-Vostok station profile on the basis of Soviet-French investigations in 1964 and 1969. Sov. Antarct. Exped. Inf. Bull., 8(5), 237-243.

Whillans, I. M. and R. A. Bindschadler. 1988. Mass balance of Ice Stream B, West Antarctica. Ann. Glaciol., 11, 187-193.

Young, N. W., M. Pourchet, V. M. Kotlyakov, P. A. Korolev and M. B. Dyugerov. 1982. Accumulation distribution in the IAGP area, Antarctica: $90^{\circ} \mathrm{E}-150^{\circ} \mathrm{E}$. Ann. Glaciol., 3, 333-338.

Zwally, H.J. 1977. Microwave emissivity and accumulation rate of polar firn. J. Glaciol., $18(79), 195-215$.

Zwally, H.J. and S. Fiegles. 1994. Extent and duration of Antarctic surface melt. 7. Glaciol., 40 (136), 463-476.

Zwally, H.J., J.C. Comiso, C. L. Parkinson, W.J. Campbell, F. D. Carsey and P. Gloersen. 1983. Antarctic sea ice, 1973-1976: satellite passive-microwave observations. Washington, DC, National Aeronautics and Space Administration. (NASA SP-459.) 